\title{
Use of non-selective $\boldsymbol{\beta}$-blockers is associated with decreased tumor proliferative indices in early stage breast cancer
}

\author{
Alexa Montoya ${ }^{1,2, *}$, Clarissa N. Amaya ${ }^{1, *}{ }^{,}$Andres Belmont ${ }^{3, *}$, Nabih Diab $^{3}$, Richard \\ Trevino ${ }^{3}$, Geri Villanueva ${ }^{3}$, Steven Rains ${ }^{1}$, Luis A. Sanchez ${ }^{4}$, Nabeel Badri ${ }^{4}$, Salman \\ Otoukesh ${ }^{4}$, Ali Khammanivong5, Danielle Liss ${ }^{4}$, Sarah T. Baca6, Renato J. Aguilera ${ }^{6}$, \\ Erin B. Dickerson ${ }^{5,7}$, Alireza Torabi ${ }^{3,8}$, Alok K. Dwivedi, ${ }^{1,3,9}$, Aamer Abbas ${ }^{3,4}$, Karinn \\ Chambers $^{3,10}$, Brad A. Bryan ${ }^{1,3}$, Zeina Nahleh ${ }^{3,4}$ \\ ${ }^{1}$ Department of Biomedical Sciences, Texas Tech University Health Sciences Center, El Paso, Texas, USA \\ ${ }^{2}$ Department of Biology, University of Texas, El Paso, Texas, USA \\ ${ }^{3}$ Paul L. Foster School of Medicine, Texas Tech University Health Sciences Center, El Paso, Texas, USA \\ ${ }^{4}$ Department of Hematology/Oncology, Loma Linda University Health Sciences Center, Loma Linda, California, USA \\ ${ }^{5}$ Department of Veterinary Clinical Sciences, University of Minnesota, Saint Paul, Minnesota, USA \\ ${ }^{6}$ Border Biomedical Research Center, University of Texas, El Paso, Texas, USA \\ ${ }^{7}$ Masonic Cancer Center, University of Minnesota, Minneapolis, Minnesota, USA \\ ${ }^{8}$ Department of Pathology, Texas Tech University Health Sciences Center, El Paso, Texas, USA \\ ${ }^{9}$ Division of Biostatistics and Epidemiology, Texas Tech University Health Sciences Center, El Paso, Texas, USA \\ ${ }^{10}$ Department of Surgery, Texas Tech University Health Sciences Center, El Paso, Texas, USA \\ *These authors contributed equally to this work \\ Correspondence to: Zeina Nahleh, email: zeina.nahleh@ttuhsc.edu \\ Brad A. Bryan, email: brad.bryan@ttuhsc.edu
}

Keywords: beta blocker, propranolol, breast cancer, proliferation, Ki-67

Received: September 07, 2016

Accepted: December 13, 2016

Published: December 23, 2016

\section{ABSTRACT}

Previous studies suggest beta-adrenergic receptor ( $\beta$-AR) antagonists ( $\beta$-blockers) decrease breast cancer progression, tumor metastasis, and patient mortality; however the mechanism for this is unknown. Immunohistochemical analysis of normal and malignant breast tissue revealed overexpression of $\beta 1-A R$ and $\beta 3-A R$ in breast cancer. A retrospective cross-sectional study of 404 breast cancer patients was performed to determine the effect of $\beta$-blocker usage on tumor proliferation. Our analysis revealed that non-selective $\beta$-blockers, but not selective $\beta$-blockers, reduced tumor proliferation by $66 \%(p<0.0001)$ in early stage breast cancer compared to non-users. We tested the efficacy of propranolol on an early stage breast cancer patient, and quantified the tumor proliferative index before and after treatment, revealing a propranolol-mediated $23 \%$ reduction $(p=0.02)$ in $\mathrm{Ki67}$ positive tumor cells over a three-week period. The anti-proliferative effects of $\beta$-blockers were measured in a panel of breast cancer lines, demonstrating that mammary epithelial cells were resistant to propranolol, and that most breast cancer cell lines displayed dose dependent viability decreases following treatment. Selective $\beta$-blockers alone or in combination were not as effective as propranolol at reducing breast cancer cell proliferation. Molecular analysis revealed that propranolol treatment of the SK-BR-3 breast cancer line, which showed high sensitivity to beta blockade, led to a reduction in Ki67 protein expression, decreased phosphorylation of the mitogenic signaling regulators p44/42 MAPK, p38 MAPK, JNK, and CREB, increased phosphorylation of the cell survival/apoptosis regulators AKT, p53, and GSK3 $\beta$. In conclusion, use of nonselective $\beta$-blockers in patients with early stage breast cancer may lead to decreased tumor proliferation. 


\section{INTRODUCTION}

Despite great advances in treatment options over the past two decades, breast cancer is still a deadly disease claiming many lives. Approximately 1.7 million women worldwide are diagnosed with breast cancer each year and one third of these women will die of this disease [1] (http://globocan.iarc.fr/Pages/fact_sheets_cancer.aspx).

Breast cancer now represents a quarter of all cancers in women worldwide and is a leading cause of cancer death in less developed countries [2]. This is partly because clinical advances, especially expensive new drugs used to combat the disease, are not reaching women living in these regions [3]. Therefore, identifying more affordable treatment options for disadvantaged patients with breast cancer remains highly desirable.

The catecholamines, epinephrine and norepinephrine, stimulate cell membrane-spanning $\beta$-ARs and mediate a variety of physiological responses including vascular smooth muscle relaxation, bronchodilation, and other processes responsive to the sympathetic nervous system [4]. Due to their roles in modulating these processes, $\beta$-AR antagonists ( $\beta$-blockers) have been used for decades to manage cardiac arrhythmias, protect against myocardial infarction, and treat hypertension [5]. Recently, several retrospective analyses of data from patients diagnosed with carcinomas have shown note-worthy responses to $\beta$-blockade including reduced cancer risk, reduced metastasis, reduced tumor-associated patient mortality, and increased progression free survival [6-15]. In contrast, other studies have found no evidence to suggest that $\beta$-blockers prevent cancer occurrence or risk of death [16-18]. Our labs have spearheaded efforts to examine the mechanism of action and clinical use of $\beta$-blockers against tumors and have reported that $\beta$-blockade disrupts proliferation, survival, migration, cell-to-matrix attachment, and global transcriptional expression patterns in vascular tumors including infantile hemangiomas and angiosarcomas [19-23]. Other labs have shown that $\beta$-AR signaling affects epithelial-to-mesenchymal transition [24] and $\beta$-blockade reduces tumor angiogenesis, cell proliferation, migration, and invasion [25-30]. Our labs and others have translated these retrospective and preclinical studies into the clinic to report that use of the $\beta$-blocker propranolol in patients with lethal angiosarcomas results in decreased tumor proliferation and sustained therapeutic responses [31-33].

Three $\beta$-ARs contribute to $\beta$-adrenergic signaling, and each plays distinctive and sometimes overlapping physiological roles largely based on their unique protein expression patterns in the human body [34]. Overexpression of $\beta$-ARs has been reported in oral squamous-cell and hepatocellular carcinomas, and their expression has been correlated with cervical lymph node metastasis, age, tumor size, and clinical stage $[35,36]$. We hypothesized that the use of $\beta$-blockers would result in reduced proliferation rates in breast cancer. Indeed, it has previously been shown using in vitro models that propranolol potentiated the anti-angiogenic and anti-tumor efficacy of chemotherapy agents in breast cancer [29]. We tested this hypothesis by assessing the expression of $\beta$-AR1, 2, and 3 in breast carcinoma tissues and performing a retrospective analysis of 404 patients to compare the proliferation rates of breast tumors in patients who had taken $\beta$-blockers in the year prior to diagnosis relative to those who had not. We corroborated our retrospective findings using a prospective window of opportunity case study on a breast cancer patient and using in vitro cell based assays on a large panel of established breast cancer cell lines.

\section{RESULTS}

\section{B1-AR and $\beta 3-A R$ are overexpressed in breast cancer}

To determine if $\beta$-ARs are aberrantly expressed in breast cancer, IHC was performed on sections of normal and cancerous breast tissue. In normal breast tissue, $\beta 1$ $\mathrm{AR}, \beta 2-\mathrm{AR}$, and $\beta 3-\mathrm{AR}$ staining was observed in both inner luminal epithelial cuboidal to columnar cells and outer myoepithelial contractile cells, yet largely absent in fibro-adipose tissues (Figure 1A). In breast cancer tissue, $\beta$-ARs were observed throughout the tumor cells and to a lesser degree within the tumor stroma (Figure 1A). IHC intensity scores were collected for each tissue evaluated, revealing that both $\beta 1$ - and $\beta 3-\mathrm{AR}$ are expressed at a higher level in breast cancer relative to normal breast tissue. A difference in $\beta 2$-AR expression was not detected between normal and breast cancer tissue (Figure 1B).

\section{Use of non-selective $\beta$-blockers is associated with reduced tumor proliferation in early stage breast cancer patients}

We carried out a retrospective study of 404 patients diagnosed with breast cancer to assess the association between use of $\beta$-blockers and breast tumor proliferation rates. No difference was found in tumor staging or hormone receptor status between users of $\beta$-blockers and non-users (Table 1, Figure 2A). However, in patients with Stage I breast cancer, use of $\beta$-blockers revealed a significant decrease in the Ki-67 based tumor proliferative index compared to patients who were non-users of $\beta$-blockers $(p=0.02)$ (Table 1, Figure 2A). In addition, a trend towards a significant ( $27 \%$ decrease; $p=0.1096$ ) association was observed between $\beta$-blocker usage and Ki67 index in Stage II breast cancer.

A recent publication suggested that only nonselective $\beta$-blockers were effective at decreasing mortality in ovarian cancer patients [15], thus we stratified our Stage I breast cancer patients based on $\beta$-AR selectivity. A significant decrease in the tumor proliferative index 
Table 1: Clinicopathological features of normal and cancer breast tissues used for $\beta$-AR IHC

\begin{tabular}{lccc}
\hline \multicolumn{1}{c}{ Characteristics } & Overall & Normal & Cancer \\
\hline \# patient samples & 25 & 5 & 20 \\
Age [mean years (s.d.)] & $48 \pm 9$ & $42 \pm 7$ & $50 \pm 9$ \\
Sex & $25 \mathrm{~F}$ & $5 \mathrm{~F}$ & $25 \mathrm{~F}$ \\
Tumor Stage & & & \\
II & 18 & N/A & 18 \\
III & 2 & N/A & 2 \\
\hline
\end{tabular}

was observed in patients taking non-selective $\beta$-blockers (Figure 2B) (control=28.9\%+/-2.2 (SEM); non-selective $\beta$-blockers $=7.1 \%+/-1.1(\mathrm{SEM}) ; p<0.0001)$. This difference was not found in Stage II, III, or IV breast cancer patients.

\section{Propranolol reduced the breast cancer proliferative index in a window of opportunity case study}

To prospectively test the findings from our retrospective study, we administered a non-selective $\beta$-blocker, propranolol, to a patient treated at the Texas Tech Breast Care Center. The patient had a diagnostic mammogram and ultrasound at baseline, showing a solid micro-lobulated mass with irregular margins at 1 o'clock position, measuring $1 \mathrm{~cm}$ in diameter. She presented with an enlarged lymph node in the left axilla $(3.5 \mathrm{~cm})$, and ultrasound guided biopsy of the left axillary lymph node revealed no evidence of metastatic carcinoma. Pathology revealed hormone receptor positive, HER2-neu negative invasive ductal carcinoma, $0.5 \mathrm{~cm} \times 1.0 \mathrm{~cm} \times 1.0 \mathrm{~cm}$, moderately differentiated, with negative surgical margins. Based on immunohistochemistry, the tumor was positive for all three $\beta$-ARs (Figure 3A). Immunohistochemistry for Ki-67 was performed on the diagnostic biopsy (pretreatment with propranolol) and on the surgical resection (post-treatment; 25 days of propranolol as indicated in the Materials and Methods section). A 23\% reduction in the mean Ki-67 proliferative index was observed in the posttreatment tumor (Mean $+/-$ SEM: 10\% $+/-1.0$ ) compared to the pre-treatment tumor (Mean +/- SEM: $13 \%+/-0.5$ ) $(p=0.02)$ (Figure 3B). Given that substantial concordance has been reported for the Ki-67 index between breast cancer core needle biopsies and their respective final surgical specimen [37], we believe this propranololmediated statistically significant decrease in tumor proliferation is valid.

\section{$\beta$-blockade reduces the proliferative index of breast cancer cell lines}

While our retrospective analysis revealed that selective $\beta$-blockers reduced the proliferative index of breast tumors, it is currently unknown whether these drugs directly affect the malignant cells within the tumor or indirectly regulate tumor proliferation through alternative mechanisms. We performed meta-analysis on a panel of established cell lines to determine the relative mRNA expression of the $A D R B \mathrm{~s}$ in non-tumor versus malignant breast cancer cells. Our data revealed that ADRBI and $A D R B 3$ mRNA was consistently expressed across all cell lines tested, while $A D R B 2$ mRNA expression exhibited variations from one cell line to another (Figure 4). It is worth noting that $A D R B 2 \mathrm{mRNA}$ is the most highly expressed ADRB gene in $\sim 90 \%$ of the cell lines tested. We subjected the panel of breast cancer cells to a dose curve of the non-selective $\beta$-blocker propranolol and measured cell viability. A primary culture of HMECs was used as a control. While cell viability of HMECs was minimally affected by even very high concentrations of propranolol $\left(\mathrm{EC}_{50}>200 \mu \mathrm{M}\right)$, cell viability in the panel of breast cancer cells was variably affected by the addition of propranolol with $\mathrm{EC}_{50}$ values ranging from $18 \mu \mathrm{M}$ to greater than $200 \mu \mathrm{M}$ depending on the cell line tested (Figure 5A, Table 2). Ki-67 staining of the SK-BR-3 line revealed that propranolol disrupted breast cancer cell proliferation (Figure 5B). To determine the molecular mechanism by which propranolol decreases breast cancer viability, we performed an antibody array and validation experiments to examine the phosphorylation status of a number of proteins involved in cell proliferation and survival. Our data revealed that 24 hour exposure of SK-BR-3 cells to $18 \mu \mathrm{M}$ propranolol (this cell line's $\mathrm{EC}_{50}$ ) resulted in decreased phosphorylation of multiple mitogenic activated protein kinases (MAPKs) as well as the cAMP responsive element binding protein (CREB), and increased phosphorylation of AKT (PKB, Protein Kinase B), glycogen synthase kinase 3 (GSK3), and p53 (Figure 5C and 5D). These data suggested that propranolol induced a cellular state indicative of reduced proliferation and increased cell stress/damage.

Similar to what was observed in the retrospective patient study described above, neither $\beta 1$-AR nor $\beta 2$-AR selective inhibitors, when used alone, were as effective as the non-selective $\beta$-blockers propranolol or carvedilol (Figure 6A, Table 3). It should be noted that nebivolol, a $\beta 1$-AR inhibitor, was more effective than any of the $\beta$-AR selective inhibitors, however this compound also exhibits a large number of off-target effects against serotonin, 

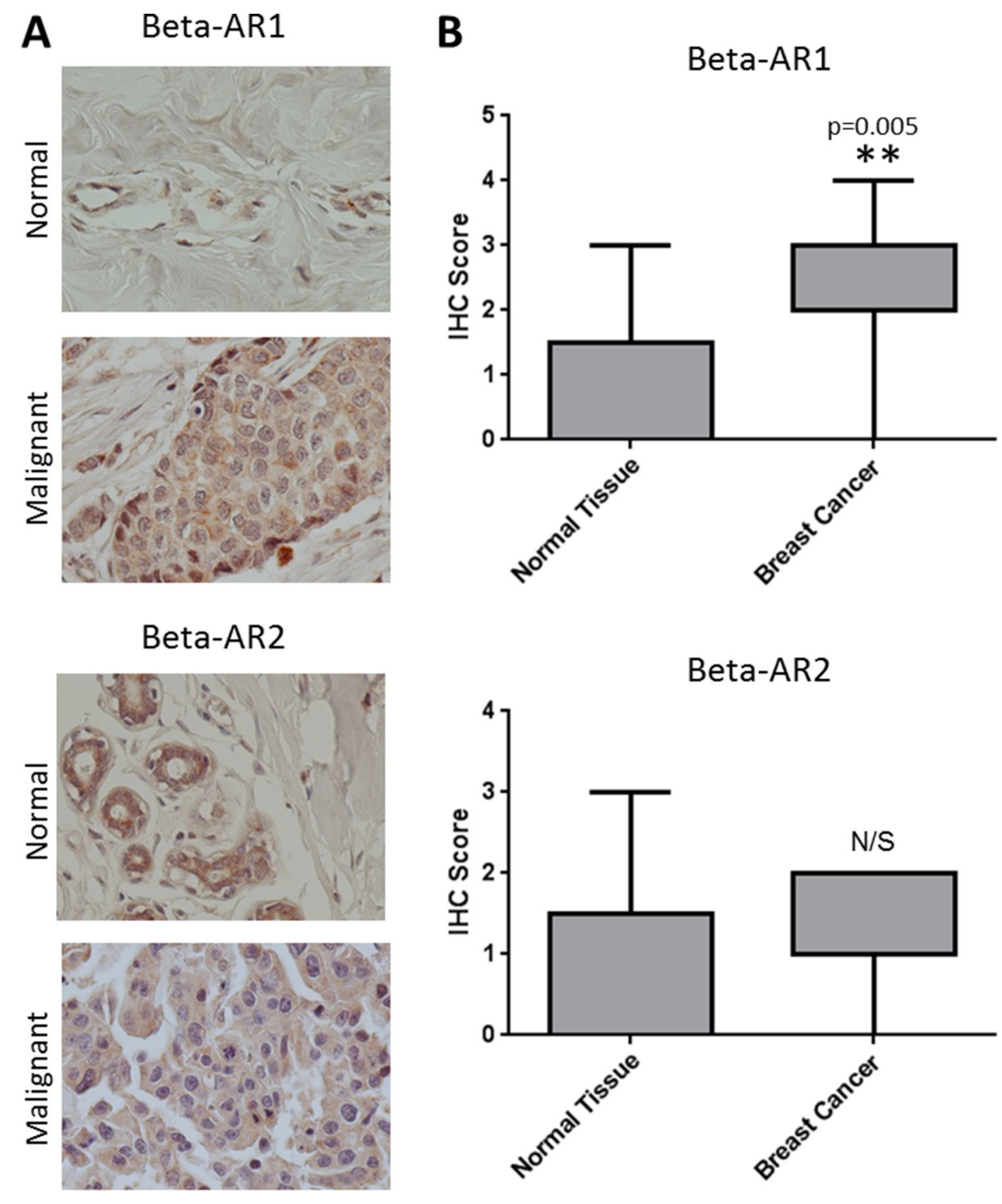

\section{Beta-AR3}
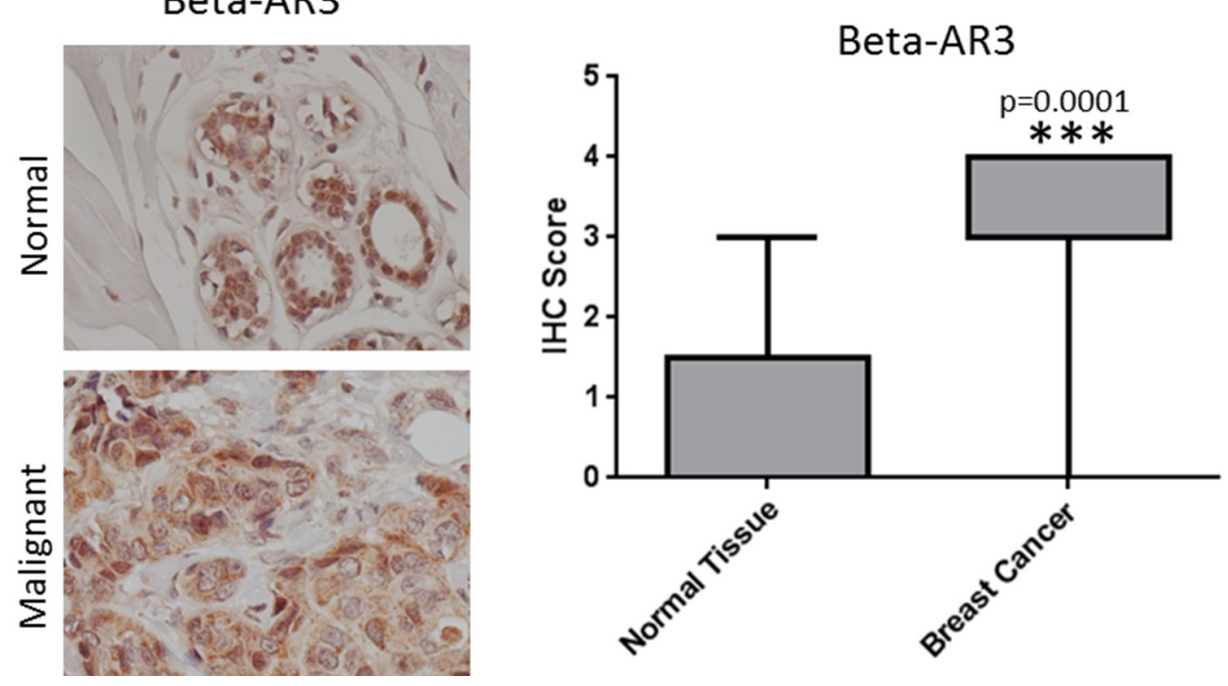

Figure 1: Overexpression of $\boldsymbol{\beta}$-ARs in breast cancer. (A) Representative images of IHC for the $\beta$-AR receptors in normal $(N=5)$ and malignant breast tissue $(N=20)$. (B) Box and whiskers plot illustrating the expression of $\beta$-ARs in the panel of normal and malignant breast tissue. 
Table 2: Association between $\beta$-blocker usage and clinicopathological characteristics in breast cancer patients

\begin{tabular}{|c|c|c|c|c|}
\hline Characteristics & $\begin{array}{c}\text { No } \beta \text {-Blocker } \\
N=349(86.4 \%)\end{array}$ & $\begin{array}{c}\beta \text {-Blocker } \\
N=55(13.6 \%)\end{array}$ & $p$ value & Significant \\
\hline \multicolumn{5}{|l|}{ Tumor stage } \\
\hline Stage I (\# patients) & $123(30.5 \%)$ & $15(3.7 \%)$ & 0.60 & No \\
\hline Stage II (\# patients) & $125(30.9 \%)$ & $19(4.7 \%)$ & & \\
\hline Stage III (\# patients) & $76(18.8 \%)$ & $15(3.7 \%)$ & & \\
\hline Stage IV (\# patients) & $25(6.2 \%)$ & $6(1.5 \%)$ & & \\
\hline \multicolumn{5}{|l|}{ Hormonal status } \\
\hline ER & & & 0.94 & No \\
\hline - (\# patients) & $95(23.5 \%)$ & $17(4.2 \%)$ & & \\
\hline + (\# patients) & $249(61.6 \%)$ & $38(9.4 \%)$ & & \\
\hline Unknown (\# patients) & $5(1.2 \%)$ & $0(0 \%)$ & & \\
\hline PR & & & 0.89 & No \\
\hline - (\# patients) & $135(33.4 \%)$ & $21(5.2 \%)$ & & \\
\hline+ (\# patients) & $209(51.7)$ & $34(8.4 \%)$ & & \\
\hline Unknown (\# patients) & $5(1.2 \%)$ & $0(0 \%)$ & & \\
\hline HER2 & & & 1.00 & No \\
\hline - (\# patients) & $255(63.1 \%)$ & $41(10.1 \%)$ & & \\
\hline + (\# patients) & $58(14.4 \%)$ & $9(2.2 \%)$ & & \\
\hline Unknown (\# patients) & $17(4.2 \%)$ & $5(1.2 \%)$ & & \\
\hline \multicolumn{5}{|l|}{ Ki-67 index } \\
\hline Stage I Mean (SEM) & $28.9(2.2)$ & $17.2(4.8)$ & 0.02 & Yes \\
\hline Non-Selective $\beta$-blocker & & $20.9(2.2)$ & 0.25 & No \\
\hline Selective $\beta$-blocker & & 7.1(1.1) & $<0.0001$ & Yes \\
\hline Stage II Mean (SEM) & $39.6(2.6)$ & $31.4(4.5)$ & 0.43 & No \\
\hline Stage III Mean (SEM) & $44.9(3.1)$ & $44.4(6.1)$ & 0.95 & No \\
\hline Stage IV Mean (SEM) & $38.3(5.3)$ & $44.0(16.5)$ & 0.67 & No \\
\hline
\end{tabular}

$\mathrm{ER}=$ estrogen receptor.

$\mathrm{PR}=$ progesterone receptor.

HER2 = HER2/neu receptor.

dopamine, histamine, and $\alpha$-AR receptors. Additionally, the non-selective $\beta$-blocker carvedilol, which also is also a noted $\alpha$-AR receptor inhibitor, was more effective at reducing breast cancer cell number than propranolol which targets $\beta$-AR receptors. Combinations of selective $\beta 1$-AR and $\beta 2$-AR inhibitors failed to produce synergy based on two independent models [38, 39] (data not shown), and these combinations, when added at their determined $\mathrm{EC}_{50}$ values for SK-BR-3 cells, also failed to replicate the decreases in viability observed following propranolol treatment (Figure 6B).

\section{DISCUSSION}

In this study, we have shown that all three $\beta$-ARs are expressed in breast cancer tissue, and $\beta 1-\mathrm{AR}$ and $\beta 3$ $\mathrm{AR}$ are overexpressed in breast cancer relative to normal breast tissue. In addition, this study suggests that use of

non-selective $\beta$-blockers in patients with early stage breast cancer may lead to decreased tumor proliferation.

Aberrant expression of $\beta 2-\mathrm{AR}$ is associated with promoting the oncogenic properties of breast cancer, increasing axillary lymph node metastasis, and leading to poor disease free survival $[40,41]$. $\beta 2$-AR potentially mediates these processes through activating a cAMPcalcium feed-forward loop to drive breast cancer cell invasion and promote invadopodia formation to enhance breast cancer cell invasion [42, 43]. While $\beta 2-\mathrm{AR}$ undoubtedly plays an important role in breast cancer, our data show that $\beta 1-\mathrm{AR}$ and $\beta 3-\mathrm{AR}$ are expressed more in breast cancer tissue relative to normal mammary epithelium at the protein level. Indeed, $\beta 1-\mathrm{AR}$ and $\beta 3-\mathrm{AR}$ are reportedly involved in cancer processes, whereby $\beta 1$ $\mathrm{AR}$ has been shown to contribute to enhanced lipolysis in cancer cachexia [44] and $\beta 3$-AR missense mutations have been correlated with obesity related breast cancer in 
Table 3: $\beta$-blocker usage identified in the retrospective study

\begin{tabular}{cccc}
\hline $\boldsymbol{\beta}$-Blocker & \# Patients & Dose Range & Selectivity \\
\hline Carvedilol & 9 & $2.12-25 \mathrm{mg}$ daily & Non-selective \\
Propranolol Sotalol & 1 & $40 \mathrm{mg}$ daily & Non-selective \\
Timolol & 1 & $160 \mathrm{mg}$ daily & Non-selective \\
Acebutolol & 1 & $0.25 \%, 2$ drops/day & Non-selective \\
Atenolol & 1 & $50 \mathrm{mg}$ daily & $\beta 1-\mathrm{AR}$ \\
Bisoprolol & 12 & $25-100 \mathrm{mg}$ daily & $\beta 1-\mathrm{AR}$ \\
Metoprolol & 1 & $6.25 \mathrm{mg}$ daily & $\beta 1-\mathrm{AR}$ \\
& 28 & $25-100 \mathrm{mg}$ daily & $\beta 1-\mathrm{AR}$ \\
\hline
\end{tabular}

African-Americans [45]. ADRB mRNA expression was not significantly different between normal and cancer cell lines, suggesting some form of translational or posttranslational regulation likely contributes to the differential expression of $\beta 1-\mathrm{AR}$ and $\beta 3-\mathrm{AR}$ protein levels between the normal and malignant tissues.

A wealth of retrospective reports supports the therapeutic utility of $\beta$-blockers in breast cancer and
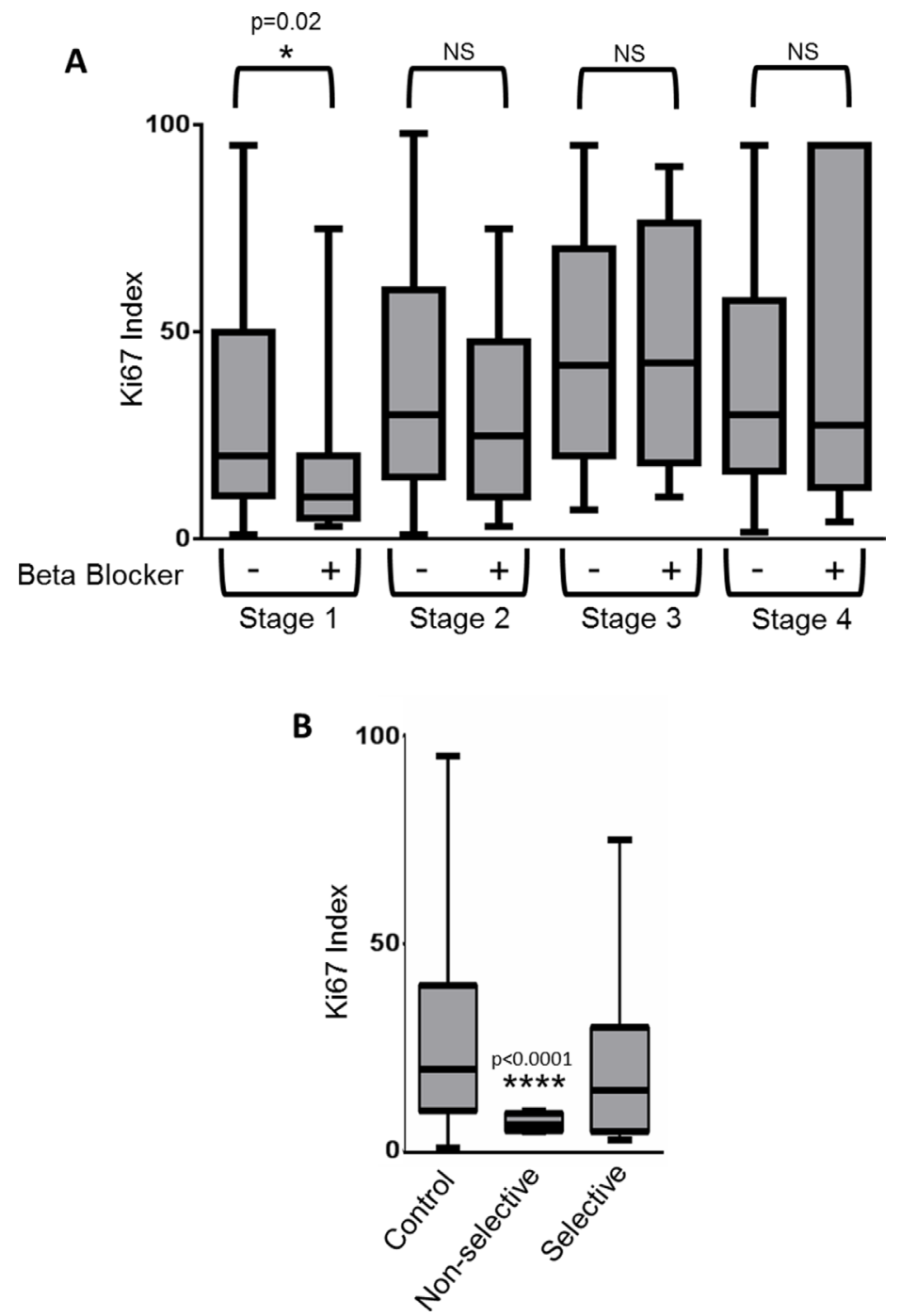

Figure 2: Use of $\beta$-blockers is correlated with a reduction in the proliferation rate of Stage I breast cancers. (A) Retrospective analysis of 404 breast cancer patients was performed to determine if use of $\beta$-blockers correlated with the tumor Ki-67 index. Box and whiskers plot illustrating the lack of correlation between $\beta$-blocker use and breast tumor proliferative rate as determined by the Ki-67 index. (B) Stage I breast cancer patients from the retrospective study were stratified based on no $\beta$-blocker use (control), or the use of non-selective or selective $\beta$-blockers. Shown is a box and whiskers plot illustrating the significant correlation between non-selective $\beta$-blockers and reduced $\mathrm{Ki}-67$ proliferative index. 
other malignancies [6-15]. While many of these retrospective studies examined therapeutic endpoints such as progression free survival and patient mortality, none have mechanistically correlated tumor response at the molecular level to $\beta$-blockade. Preclinical studies in diverse cancers have revealed that $\beta$-blockade decreases tumor cell proliferation rates [21, 27, 46-49]. In this study we sought to determine if $\beta$-blockade affects tumor cell proliferation in a large patient population stricken with a very common tumor type. Our data showed significant association between the use of non-selective $\beta$-blockers and breast cancer proliferation rate, revealing an over $75 \%$ reduction in the proliferation rate of Stage I breast cancer following use of non-selective $\beta$-blockers such as carvedilol, propranolol, or sotalol. These data suggest a possible use for non-selective $\beta$-blockers in breast cancer prevention or in the treatment of early stage disease before the development of advanced tumors. Moreover, the efficacy of non-selective over selective $\beta$-blockers corroborates previously reported data revealing that non-selective $\beta$-blockers, but not selective $\beta$-blockers, were effective at reducing mortality in ovarian cancer patients [15].

Our in vitro cell line-based data demonstrated that there was no correlation between the sensitivity of the breast cancer cell lines for beta blockade and their respective levels of $\beta$-AR mRNA expression. In cell lines we corroborated our retrospective and prospective analyses, showing that non-selective beta blockade was more effective at reducing breast cancer cell viability than selective beta blockade. Based on our expression data, both of the non-selective beta blockers, propranolol and carvedilol, were more effective than any selective beta blocker, and we suspect the increased efficacy of carvedilol over propranolol was based on carvedilol's added alpha-1 adrenergic ( $\alpha 1-\mathrm{AR})$ receptor inhibitor activity $\left(\mathrm{K}_{\mathrm{i}}=2.2 \mathrm{nM}\right)$. Only nebivolol, a third generation $\beta 1$-AR selective inhibitor, came close to recapitulating the activity of the non-selective beta blockers, however this compound exhibits the highest $\beta 1$-AR affinity among $\beta$-blockers, uniquely stimulates the activity of nitric oxide synthase, and has a number of off-target effects including a1-AR $\left(\mathrm{K}_{\mathrm{i}}=1.2 \mu \mathrm{M}\right)$, serotonin 5-HT1a $\left(\mathrm{K}_{\mathrm{i}}=20 \mathrm{nM}\right)$, serotonin 5-HT2 $\left(\mathrm{K}_{\mathrm{i}}=700 \mathrm{nM}\right)$, dopamine $\left(\mathrm{K}_{\mathrm{i}}=4 \mu \mathrm{M}\right)$, and histamine $\mathrm{H} 1$ receptor $\left(\mathrm{K}_{\mathrm{i}}=2.4 \mu \mathrm{M}\right)$ which may contribute to its enhanced efficacy relative to other selective $\beta 1-\mathrm{AR}$ inhibitors. Indeed, many of these off-target pathways are reportedly novel anti-cancer targets [50-53]. No synergism was calculated based on combinations of $\beta 1$ $\mathrm{AR}$ and $\beta 2-\mathrm{AR}$ antagonists, and these combinations were incapable of recapitulating the anti-proliferative effects of the non-selective $\beta$-blocker propranolol, suggesting the
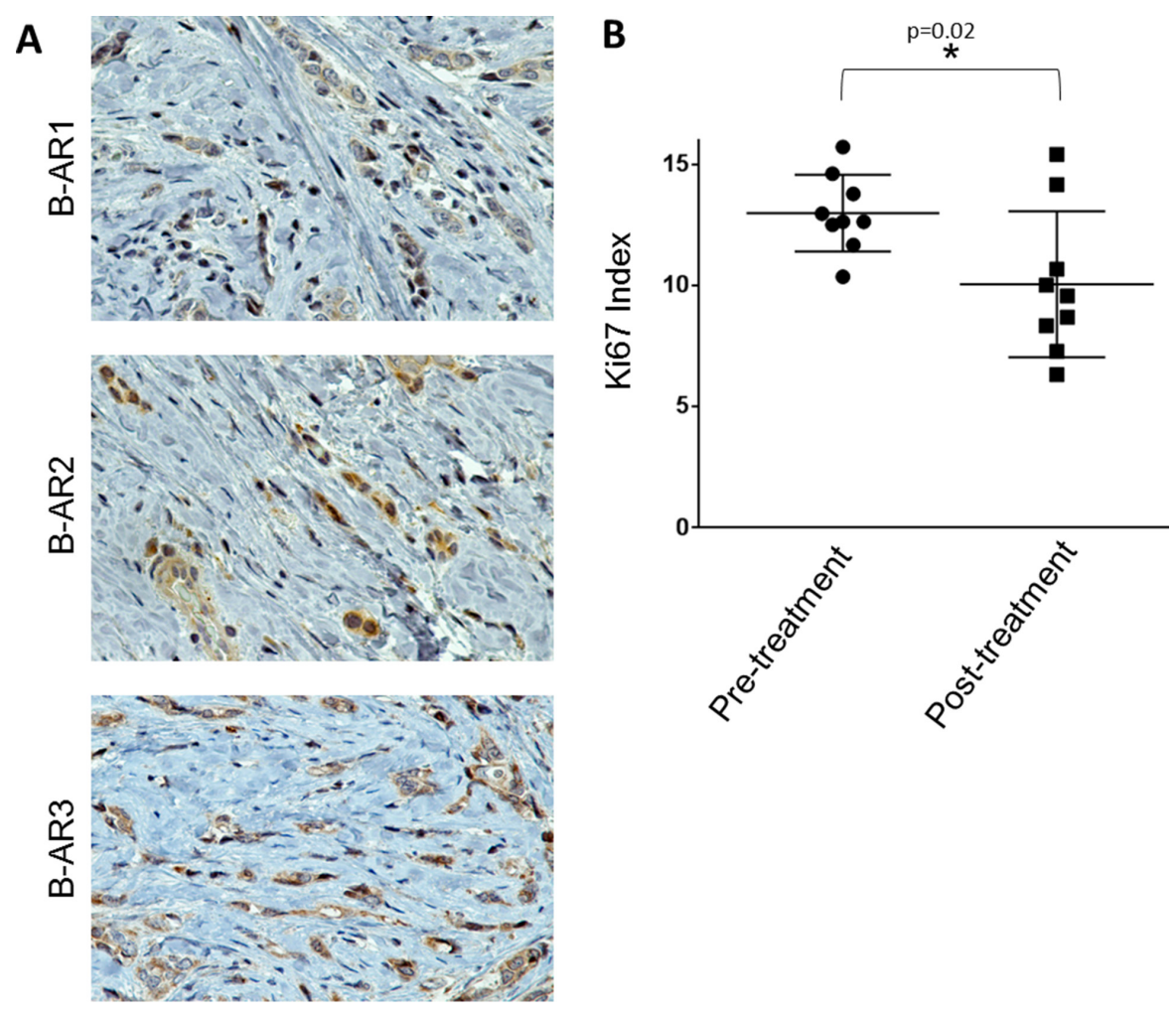

Figure 3: Testing the efficacy of propranolol in a prospective window of opportunity breast cancer case study. (A) Representative 600x images of IHC for the $\beta$-AR receptors in a patient diagnosed with Stage I, hormonal receptor positive, HER2-neu negative ductal carcinoma breast cancer. (B) The patient was given propranolol as indicated in the materials and methods section over a 25-day period. Ki-67 IHC was performed on the diagnostic biopsy before propranolol treatment began (pre-treatment) and at the surgical resection after 25 days propranolol (post-treatment). The scatter plot depicts the Ki-67 index pre- and post-treatment across 9 vision fields with over 250 cells/field. 


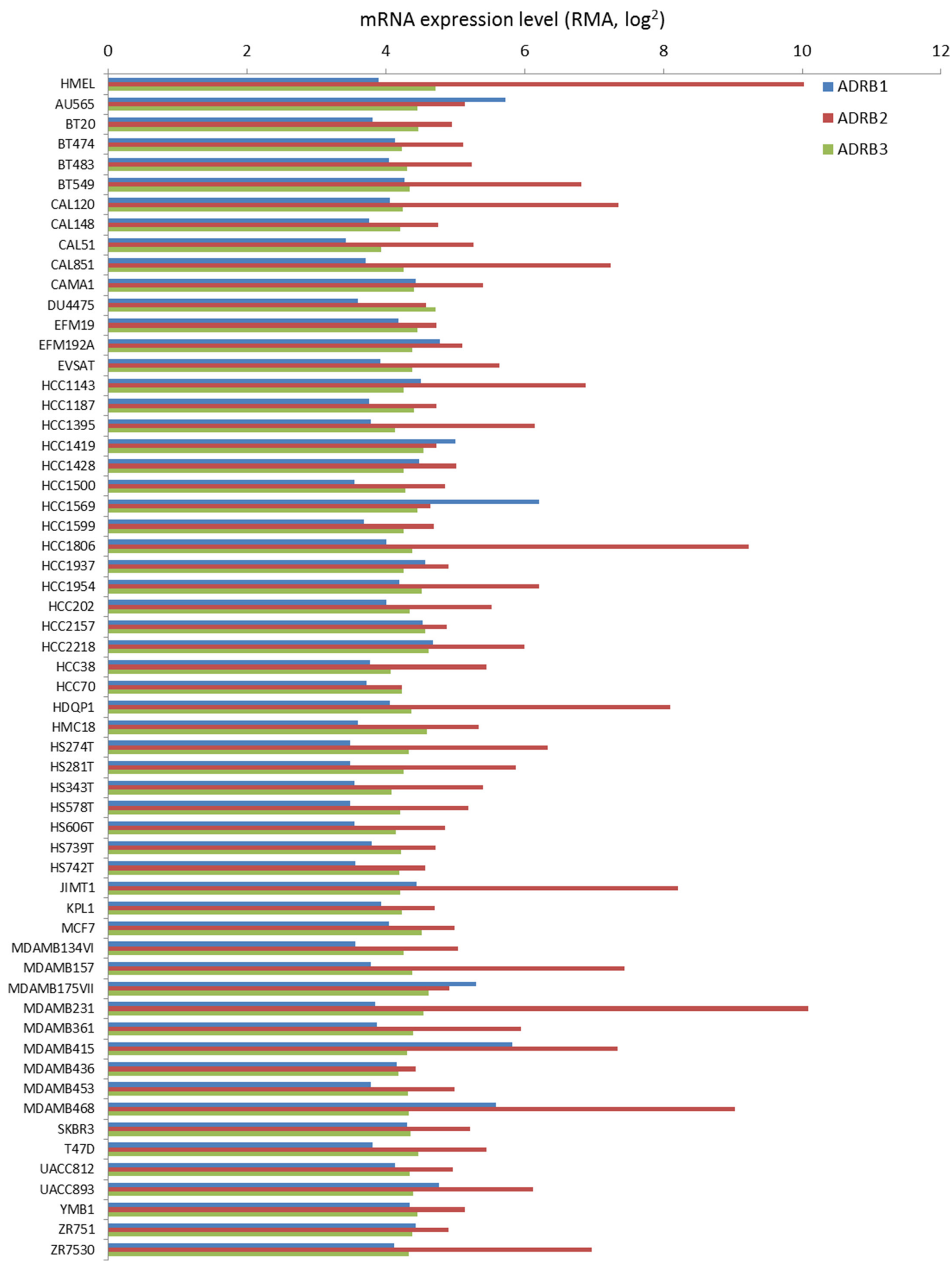

Figure 4: ADRB mRNA expression across a panel of normal and malignant breast cell lines. mRNA expression of ADRB1, ADRB2, and ADRB3 across a panel of established breast cancer lines based on data housed in the CCLE database. Expression of the mRNAs in a human immortalized mammary epithelial cell line (HMEL) was used as a control. 

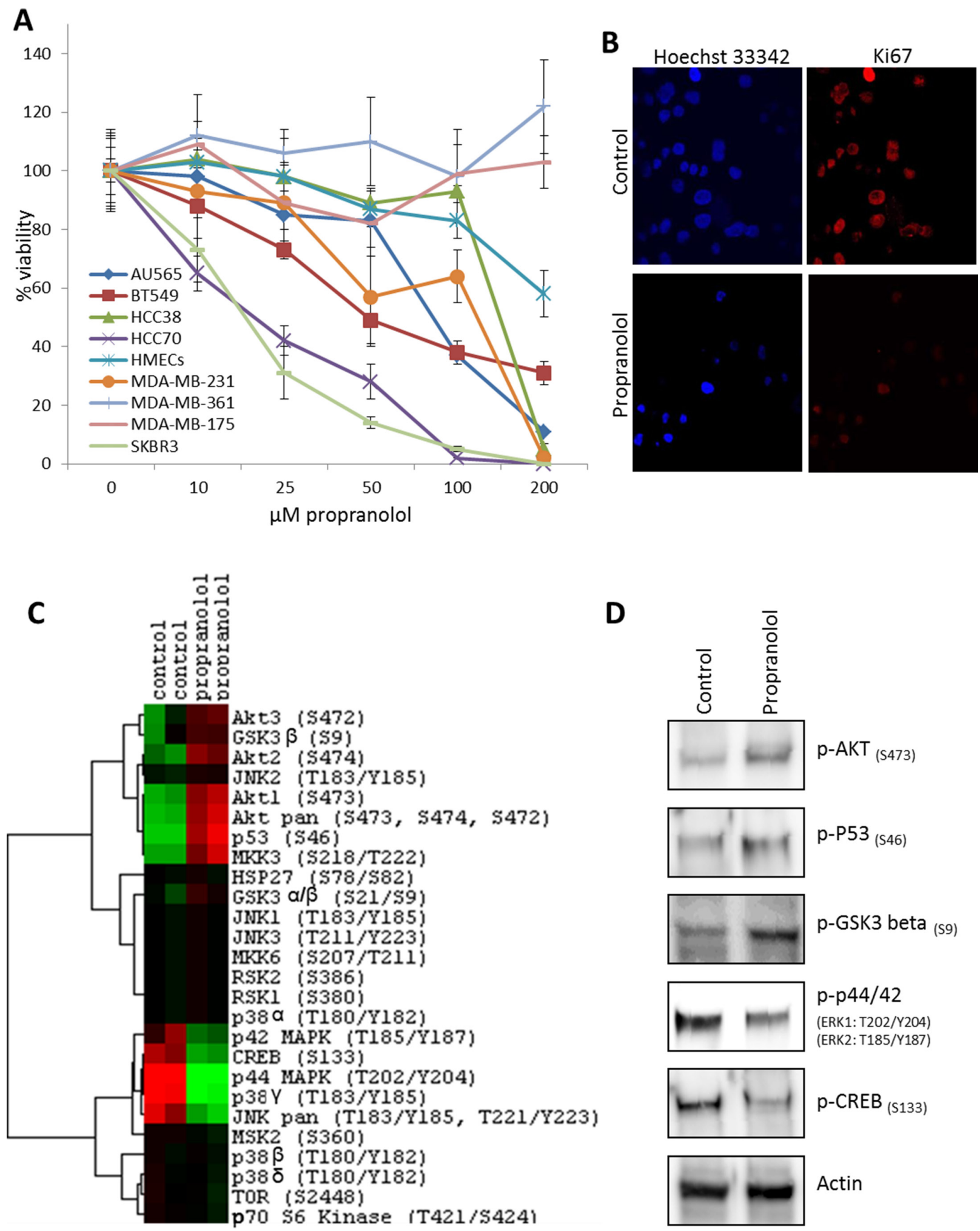

Figure 5: $\boldsymbol{\beta}$-blockers inhibit the proliferation of breast cancer cell lines. (A) A dose curve of propranolol was administered to a panel of breast cancer cell lines and normal primary mammary epithelial cells (HMECS) and viability was assessed. (B) Immunofluorescent detection of Ki-67 protein expression in control or propranolol-treated $(18 \mu \mathrm{M})$ SK-BR-3 breast cancer cells after 24 hours. Hoechst 33342 was used as a nuclear counterstain. (C) Heatmap depicting phospho-MAPK antibody array results testing the status of 24 kinases in SK-BR-3 cells subjected to 24 hours control or propranolol $(18 \mu \mathrm{M})$. (red = upregulated; green = downregulated; black = no detectable expression). (D) Western blot confirmation of the antibody array results in SK-BR-3 cells subjected to 24 hours control or propranolol $(18 \mu \mathrm{M})$. (D) Western blot analysis of cell lysates from SK-BR-3 cells subjected to 24 hours control or propranolol (18 $\mu \mathrm{M})$, confirming the phosphorylation events identified in the antibody array. 
potential that off target effects partially contribute to the effectiveness of non-selective beta blockers against breast cancer cell lines. As mentioned above, carvedilol exhibits off target effects on $\beta 1-\mathrm{AR}$, and propranolol demonstrates high affinity for serotonin 5-HT1B receptors $\left(\mathrm{K}_{\mathrm{i}}=17 \mathrm{nM}\right)$ and mild affinity for serotonin 5HT-1D receptors $\left(\mathrm{K}_{\mathrm{i}}=10.2 \mu \mathrm{M}\right)$. In summary, future prospective clinical trials testing $\beta$-blockers in breast cancer should focus on using non-selective $\beta$-blockers such as propranolol or nonselective $\alpha$-AR/ $\beta$-AR inhibitors such as carvedilol against early stage disease.

Our retrospective data analysis has some limitations. First, due to retrospective data collection, we could not determine the long-term effect of using $\beta$-blockers. Second, our data comprised only a small proportion of $\beta$-blocker users $(\sim 13 \%$ of the patients). Therefore,
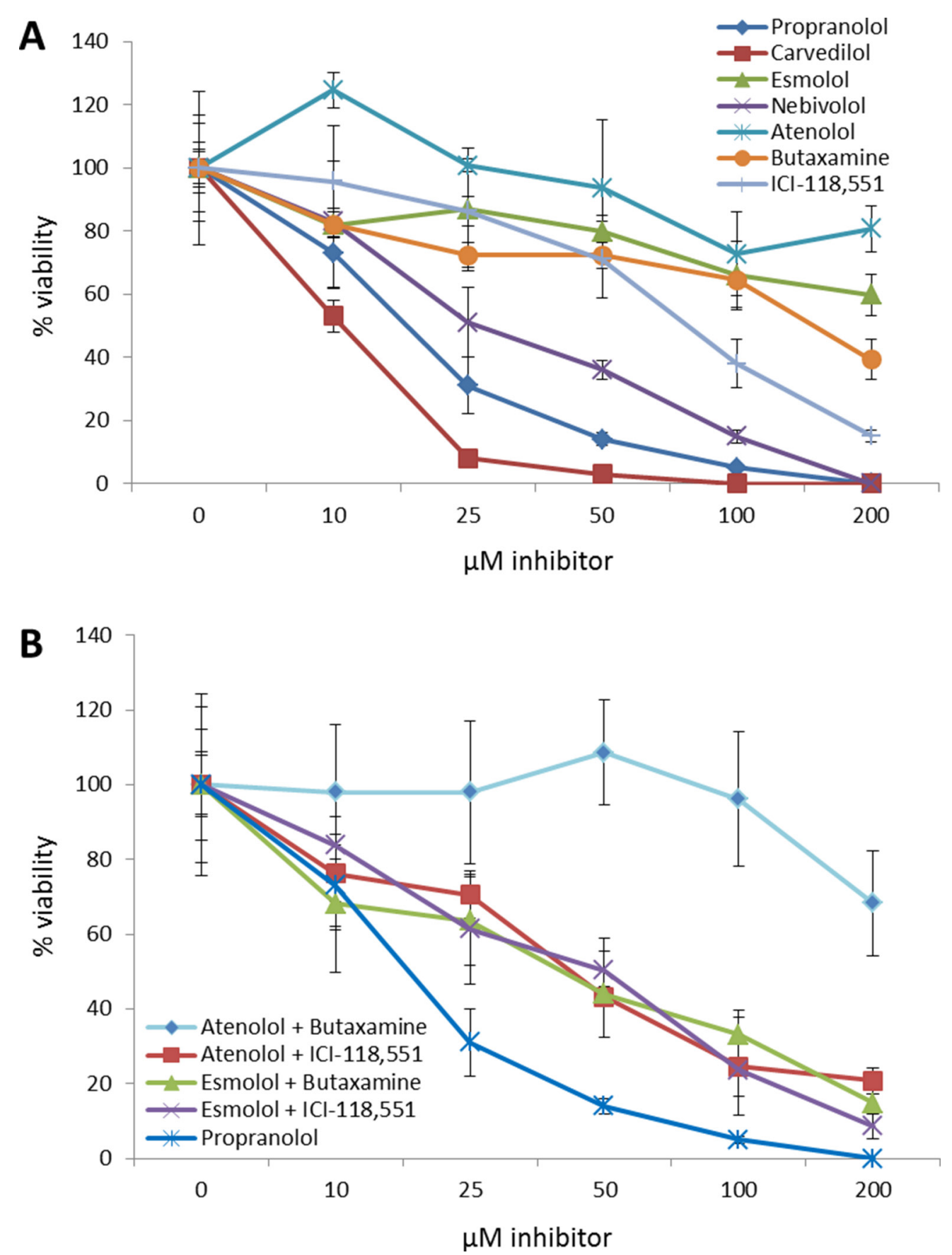

Figure 6: Non-selective beta blockers exhibit higher efficacy than selective beta blockers at decreasing breast cancer cell viability. (A) Dose curves of $\beta 1$-AR or $\beta 2$-AR selective antagonists were administered to the SK-BR-3 breast cancer cell line and cell viability was assayed and compared to propranolol. (B) Dose curves of $\beta 1$-AR and $\beta 2$-AR selective antagonist combinations at their determined $\mathrm{EC}_{50}$ values were administered to the SK-BR-3 breast cancer cell line and cell viability was assayed and compared to propranolol. 
we could not adjust for any differences in the baseline cofactors while determining association of $\beta$-blockers with Ki-67. Third, we could not collect any other medication data or commodities data which might modify the effect of $\beta$-blockers on $\mathrm{Ki}-67$. Nonetheless, our retrospective data analysis along with laboratory experimental studies, prospective study, and bioinformatics meta-analysis study provide ample evidence that non-selective $\beta$-blockers could be effective in reducing Ki-67 among early stage breast cancer. Moreover, interpretation of a single prospective case report must be taken with caution and further clinical studies are needed to corroborate these findings.

If the wealth of preclinical, retrospective, and clinical data continue to support the use of $\beta$-blockers as a supplement to existing anti-cancer therapeutic regimes, this class of drugs could be used as safe, low cost therapeutics that are especially useful in the era of prohibitively costly new anti-cancer therapeutics, most particularly in low resource settings where many cancer patients do not possess the financial means or access to expensive novel treatments.

\section{MATERIALS AND METHODS}

\section{Immunohistochemical analysis of $\beta$-AR expression in breast tissue}

Immunohistochemistry (IHC) for $\beta 1-\mathrm{AR}, \beta 2-\mathrm{AR}$, and $\beta 3-\mathrm{AR}$ expression was performed on tissue arrays composed of five normal, fibrofatty breast tissues and twenty invasive, ductal carcinoma tissues (US Biomax, Cat\# MC5003b). The known clinicopathological features associated with these tissues are described in Table 4. Sections were deparaffinized, rehydrated, and treated for antigen retrieval using Trilogy (Cell Marque). Nonspecific binding was blocked with background block solution (Cell Marque). The following primary antibodies were used for antigen detection: anti- $\beta 1-\mathrm{AR}$ (1:200, Abbiotech Cat\# 250919), anti- $\beta 2-A R$ (1:200, Abbiotech Cat\# 251604), anti-ß3-AR (1:200, Abbiotech Cat\# 251604), and anti-Ki-67 (1:200, Abcam Cat\# ab15580). Each anti- $\beta$-AR antibody was raised against synthetic peptides unique and non-overlapping for each protein. Specificity was tested based on western blotting bands from cancer cell line lysates matching to the appropriate molecular weight for each protein; no overlap in antigenicity was observed (data not shown). Sections were incubated with the CytoScan Alkaline Phos Detection System (Cell Marque) and detected using the DAB substrate kit (Cell Marque). All slides were counterstained with hematoxylin. Immunopositive staining was semi-quantitatively evaluated by 2 individuals blinded to sample identification based on staining intensity within the tumor-positive areas of the tissue.

\section{Retrospective study}

Analysis of 404 female patients diagnosed with invasive ductal carcinoma at the Texas Tech Breast Care Center between the years of 2005 to 2014 was performed. $90.1 \%$ of the patients were Hispanic. IHC for estrogen receptor (ER), progesterone receptor (PR), Her-2/neu, and $\mathrm{Ki}-67$ tumor proliferative index was available for all patients. Breast cancer clinico-pathological features (age at diagnosis, tumor size, tumor grade, lymph node status, hormonal receptor status) were extracted from each case report, and these data are presented in Table 1. Patients were considered positive for $\beta$ blocker usage if they had been prescribed $\beta$-blockers at any point in the year immediately prior to diagnosis. In total, we identified 54 patients taking $\beta$-blockers $(61.0+/-10$ years old) and 350 patients (54.6 $+/-12$ years old) that were not taking $\beta$-blockers during the defined time frame. Non-selective $\beta$-blockers were prescribed to $22 \%$ of the patients, while $78 \%$ of the patients were prescribed selective $\beta$-blockers (Table 5).

\section{Prospective window of opportunity case study}

A patient diagnosed with Stage I, hormonal receptor positive, HER2-neu negative ductal carcinoma was seen and enrolled in the study at the Texas Tech Breast Care Center. The patient was prescribed $1.5 \mathrm{mg} / \mathrm{kg} /$ day propranolol for 18 days and then a tapering dose over the subsequent 7 days. The tapering dose was required by IRB and after consultation with a cardiologist. In total, the patient was administered propranolol for 25 days. The dose of propranolol used in this study was within the typical range of $80-320 \mathrm{mg}$ per day prescribed for ailments such as hypertension, angina pectoris, myocardial infarction, and hemangioma. IHC was performed to confirm the expression of all three $\beta$-ARs. Ki-67 immunohistochemistry (1:200, Abcam Cat\# ab15580) was performed on tissue sections from the diagnostic biopsy (pre-treatment with propranolol) and on the surgical resection of the tumor (post-treatment with propranolol). The Ki-67 index was blindly quantified in both the preand post-treatment tissues by counting 9 fields under a microscope, with each field composed of $250+$ nuclei. The Ki-67 index was calculated as the (number of Ki-67 positive nuclei/total number of nuclei) $\times 100$.

\section{Meta-analysis of breast cancer cell line genomics data}

Quantile normalized mRNA expression (Affymetrix U133+2 arrays) for human breast cancer and immortalized mammary epithelial (HMEL) cell lines were downloaded from the Broad Institute Cancer Cell Line Encyclopedia (CCLE) database (http://www. broadinstitute.org/ccle) [54]. The data were processed using GENE-E (The Broad Institute of MIT and 
Table 4: $\mathrm{EC}_{50}$ values for propranolol in normal and malignant breast cell lines

\begin{tabular}{lr}
\hline Cell Line & EC $_{\mathbf{5 0}}$ \\
\hline HMEC & $>200 \mu \mathrm{M}$ \\
AU565 & $81 \mu \mathrm{M}$ \\
BT549 & $50 \mu \mathrm{M}$ \\
HCC38 & $93 \mu \mathrm{M}$ \\
HCC70 & $20 \mu \mathrm{M}$ \\
MDA-MB-175 & $>200 \mu \mathrm{M}$ \\
MDA-MB-231 & $78 \mu \mathrm{M}$ \\
MDA-MB-361 & $>200 \mu \mathrm{M}$ \\
SK-BR-3 & $18 \mu \mathrm{M}$ \\
\hline
\end{tabular}

Table 5: EC $_{50}$ values for selective and non-selective $\beta$-blockers in SK-BR-3 breast cancer cells

\begin{tabular}{lll}
\hline $\boldsymbol{\beta}$-blocker & Selectivity & $\mathbf{E C}_{\mathbf{5 0}}$ \\
\hline Propranolol & Non-selective & $18 \mu \mathrm{M}$ \\
Carvedilol & Non-Selective & $11 \mu \mathrm{M}$ \\
Esmolol & $\beta 1$-AR & $>200 \mu \mathrm{M}$ \\
Nebivolol & $\beta 1-\mathrm{AR}$ & $32 \mu \mathrm{M}$ \\
Atenolol & $\beta 1-\mathrm{AR}$ & $>200 \mu \mathrm{M}$ \\
Butaxamine & $\beta 2-\mathrm{AR}$ & $144 \mu \mathrm{M}$ \\
ICI-118,551 & $\beta 2-\mathrm{AR}$ & $81 \mu \mathrm{M}$ \\
\hline
\end{tabular}

Harvard, http://www.broadinstitute.org/cancer/software/ GENE-E).

\section{Viability assays}

Normal breast and breast cancer cell lines were cultured in incubators maintained at 37 degrees Celsius in the presence of $5 \% \mathrm{CO}_{2}$. Primary cultures of normal human mammary epithelial cells (HMECs; ATCC \#PCS-600-010) were grown in the EBM-2 bullet kit (Lonza) with penicillin/ streptomycin antibiotics. MDA-MB-361 (ATCC \#HTB-27) was grown in Leibovitz's L-15 medium supplemented with $20 \%$ fetal bovine serum and penicillin/streptomycin antibiotics. AU565 (ATCC \#CRL-2351), HCC70 (ATCC \#CRL-2115), BT-549 (ATCC \#HTB-122), HCC38 (ATCC \# CRL-2314), and MDA-MB-231 (ATCC \#HTB-26) were grown in RPMI 1640 medium supplemented with $10 \%$ fetal bovine serum and penicillin/streptomycin antibiotics. SKBR-3 (ATCC \#HTB-30) was grown in McCoy's medium supplemented with $10 \%$ fetal bovine serum and penicillin/ streptomycin antibiotics. All cell lines were used for less than 6 months from the date of purchase and were characterized by ATCC based on morphology, karyotyping, and PCR based approaches to confirm their identify and rule out intra- and inter-species contamination. DL-propranolol hydrochloride (Acros Organics), carvedilol (Tocris Bioscience), esmolol (Santa Cruz Biotechnology), nebivolol (Santa Cruz Biotechnology), atenolol (Acros Organics), butaxamine hydrochloride (Santa Cruz Biotechnology), and ICI 118,551 hydrochloride (Santa Cruz Biotechnology) was added to the cell lines at the indicated concentrations, and cell viability was assessed after 48 hours by alamar blue cell viability assays (ThermoScientific). Two models, the Bliss Independence Model [38] and the Linear Interaction Effect Model [39], were used to evaluate drug combination synergy.

\section{Immunofluorescence}

SK-BR-3 cells were treated with propranolol for 24 hours and subsequently fixed in $4 \%$ paraformaldehyde. Cells were permeabilized with Triton X-100 and incubated with an anti-Ki-67 antibody (1:400, Abcam Cat\# ab15580) and anti-rabbit secondary antibodies conjugated to AlexaFlour 594 dye (ThermoFisher). Hoechst 33342 was used as a nuclear stain. Confocal images were obtained using a Nikon Eclipse T $i$.

\section{Antibody array}

The Phospho-Mitogen-activated Protein Kinase (MAPK) Antibody Array (R\&D Systems \#ARY002B) was performed on SK-BR-3 cells treated for 24 hours with either a control or $18 \mu \mathrm{M}$ propranolol according to the manufacturer's instructions. Data was centered, normalized, and clustered using a centroid linkage via an un-centered similarity metric with Cluster 
3.0 software. Heatmaps were visualized using Java Treeview software.

\section{Western blotting}

Protein extracts from SK-BR-3 cells were separated by SDS-PAGE, transferred onto PVDF membranes, and probed with antibodies against phospho-AKT (S473) (Cell Signaling \#9271), phospho-p53 (S46) (Cell Signaling \#2521), phospho-GSK3 $\beta$ (S9) (Cell Signaling \#5558), phospho-p44/42 (ERK1: T202/Y204; ERK2: T185/Y187) (R\&D Systems \#AF1018), phospho-CREB (S133) (Cell Signaling \#9196), and actin (Santa Cruz Biotechnology \#sc47778). Proteins were detected with HRP-conjugated secondary antibodies and visualized with the Pierce ECL Western blotting substrate (ThermoScientific) according to the manufacturer's protocol.

\section{Statistical analysis}

For statistical analysis of $\beta$-AR expression in breast tissue, the Mann-Whitney rank sum test was used. For the retrospective study of breast cancer patient data, the relationship between $\beta$-blocker usage and the Ki-67-based proliferative index of the breast tumors was determined with the Mann-Whitney rank sum test. Ki-67 was used to measure tumor proliferation given its established role as a proliferative marker [55], and we have previously demonstrated that the expression of this protein provides a very good concordance with the Recurrence Score Pathology-Clinical (RSPC value) in breast cancer in our pathology lab [56]. Unpaired $t$-test was used to compare the age distribution between $\beta$-blocker users and nonusers. Comparisons of $\beta$-blocker usage to tumor hormonal receptor status and tumor staging were calculated with the Fisher's exact test. Paired $t$-tests were used to compare Ki-67 expression in the prospective pre- and post-treatment breast cancer patient sample. Statistical analyses were carried out using STATA 13. Differences were considered statistically significant if the $p$ value was less than 0.05 .

\section{ACKNOWLEDGMENTS}

We would like to thank Dolores Diaz and Jaime Rios (Texas Tech University Health Sciences Center Histology Core Facility) for their assistance with immunohistochemistry.

\section{CONFLICTS OF INTEREST}

The authors declare they have no competing interests.

\section{GRANT SUPPORT}

This project was supported by grants to ZN (CPRIT RP120528), ZN and BAB (TTUHSC-El Paso seed grant \#533701), and RJA (NIGMS 1SC3GM103713-2; NIMDH 5G12MD007592-22).

\section{REFERENCES}

1. Narod SA, Iqbal J, Giannakeas V, Sopik V, Sun P. Breast Cancer Mortality After a Diagnosis of Ductal Carcinoma In Situ. JAMA oncology. 2015; 1:888-896.

2. Jemal A, Bray F, Center MM, Ferlay J, Ward E, Forman D. Global cancer statistics. CA Cancer J Clin. 2011; 61:69-90.

3. Forouzanfar MH, Foreman KJ, Delossantos AM, Lozano R, Lopez AD, Murray CJ, Naghavi M. Breast and cervical cancer in 187 countries between 1980 and 2010: a systematic analysis. Lancet. 2011; 378:1461-1484.

4. Bangalore S, Messerli FH, Kostis JB, Pepine CJ. Cardiovascular protection using beta-blockers: a critical review of the evidence. Journal of the American College of Cardiology. 2007; 50:563-572.

5. Bonsu KO, Owusu IK, Buabeng KO, Reidpath DD, Kadirvelu A. Review of novel therapeutic targets for improving heart failure treatment based on experimental and clinical studies. Therapeutics and clinical risk management. 2016; 12:887-906.

6. Armaiz-Pena GN, Allen JK, Cruz A, Stone RL, Nick AM, Lin YG, Han LY, Mangala LS, Villares GJ, Vivas-Mejia P, Rodriguez-Aguayo C, Nagaraja AS, Gharpure KM, et al. Src activation by beta-adrenoreceptors is a key switch for tumour metastasis. Nature communications. 2013; 4:1403.

7. Barron TI, Connolly RM, Sharp L, Bennett K, Visvanathan K. Beta blockers and breast cancer mortality: a population-based study. Journal of clinical oncology. 2011; 29:2635-2644.

8. Bir SC, Kalakoti P, Ahmed O, Bollam P, Nanda A. Elucidating the role of incidental use of beta-blockers in patients with metastatic brain tumors in controlling tumor progression and survivability. Neurology India. 2015; 63:19-23.

9. Chang PY, Huang WY, Lin CL, Huang TC, Wu YY, Chen JH, Kao CH. Propranolol Reduces Cancer Risk: A Population-Based Cohort Study. Medicine. 2015; 94:e1097.

10. Childers WK, Hollenbeak CS, Cheriyath P. beta-Blockers Reduce Breast Cancer Recurrence and Breast Cancer Death: A Meta-Analysis. Clinical breast cancer. 2015; 15:426-431.

11. Grytli HH, Fagerland MW, Fossa SD, Tasken KA. Association between use of beta-blockers and prostate cancer-specific survival: a cohort study of 3561 prostate cancer patients with high-risk or metastatic disease. European urology. 2014; 65:635-641.

12. Melhem-Bertrandt A, Chavez-Macgregor $M$, Lei $X$, BrownEN, Lee RT, Meric-Bernstam F, Sood AK, Conzen SD, Hortobagyi GN, Gonzalez-Angulo AM. 
Beta-blocker use is associated with improved relapse-free survival in patients with triple-negative breast cancer. Journal of clinical oncology. 2011; 29:2645-2652.

13. Nkontchou G, Aout M, Mahmoudi A, Roulot D, Bourcier V, Grando-Lemaire V, Ganne-Carrie N, Trinchet JC, Vicaut E, Beaugrand M. Effect of long-term propranolol treatment on hepatocellular carcinoma incidence in patients with HCVassociated cirrhosis. Cancer prevention research. 2012; 5:1007-1014.

14. Powe DG, Voss MJ, Zanker KS, Habashy HO, Green AR, Ellis IO, Entschladen F. Beta-blocker drug therapy reduces secondary cancer formation in breast cancer and improves cancer specific survival. Oncotarget. 2010; 1:628-638. doi: 10.18632/oncotarget.101009.

15. Watkins JL, Thaker PH, Nick AM, Ramondetta LM, Kumar S, Urbauer DL, Matsuo K, Squires KC, Coleman RL, Lutgendorf SK, Ramirez PT, Sood AK. Clinical impact of selective and nonselective beta-blockers on survival in patients with ovarian cancer. Cancer. 2015; 121:3444-3451.

16. Cardwell CR, Coleman HG, Murray LJ, O'Sullivan JM, Powe DG. Beta-blocker usage and prostate cancer survival: a nested case-control study in the UK Clinical Practice Research Datalink cohort. Cancer epidemiology. 2014; 38:279-285.

17. Numbere B, Fleming KM, Walker A, Card TR. Adrenergic blockers and the risk for common solid cancers: a casecontrol study. European journal of cancer prevention. 2015.

18. Shah SM, Carey IM, Owen CG, Harris T, Dewilde S, Cook DG. Does beta-adrenoceptor blocker therapy improve cancer survival? Findings from a populationbased retrospective cohort study. British journal of clinical pharmacology. 2011; 72:157-161.

19. Bryan BA. Reconsidering the Use of Propranolol in the Treatment of Cosmetic Infantile Hemangiomas. Angiology open access. 2013; 1.

20. Stiles J, Amaya C, Pham R, Rowntree RK, Lacaze M, Mulne A, Bischoff J, Kokta V, Boucheron LE, Mitchell DC, Bryan BA. Propranolol treatment of infantile hemangioma endothelial cells: A molecular analysis. Experimental and therapeutic medicine. 2012; 4:594-604.

21. Stiles JM, Amaya C, Rains S, Diaz D, Pham R, Battiste J, Modiano JF, Kokta V, Boucheron LE, Mitchell DC, Bryan BA. Targeting of beta adrenergic receptors results in therapeutic efficacy against models of hemangioendothelioma and angiosarcoma. PloS one. 2013; 8:e60021.

22. Verma K, Tran D, Bryan BA, Mitchell DC. Meta-analysis of Infantile Hemangioma Endothelial Cell Microarray Expression Data Reveals Significant Aberrations of Gene Networks Involved in Cell Adhesion and Extracellular Matrix Composition. Angiology open access. 2013; 1.

23. Dickerson EB, Bryan BA. Beta Adrenergic Signaling: A Targetable Regulator of Angiosarcoma and Hemangiosarcoma. Veterinary Sciences. 2015; 2:270-292.
24. Zhang J, Deng YT, Liu J, Wang YQ, Yi TW, Huang BY, He SS, Zheng B, Jiang Y. Norepinephrine induced epithelial-mesenchymal transition in HT-29 and A549 cells in vitro. Journal of cancer research and clinical oncology. 2016; 142:423-435.

25. Iseri OD, Sahin FI, Terzi YK, Yurtcu E, Erdem SR, Sarialioglu F. beta-Adrenoreceptor antagonists reduce cancer cell proliferation, invasion, and migration. Pharmaceutical biology. 2014; 52:1374-1381.

26. Le CP, Nowell CJ, Kim-Fuchs C, Botteri E, Hiller JG, Ismail H, Pimentel MA, Chai MG, Karnezis T, Rotmensz N, Renne G, Gandini S, Pouton CW, et al. Chronic stress in mice remodels lymph vasculature to promote tumour cell dissemination. Nature communications. 2016; 7:10634.

27. McAllister SC, Hanson RS, Manion RD. Propranolol Decreases Proliferation of Endothelial Cells Transformed by Kaposi's Sarcoma-Associated Herpesvirus and Induces Lytic Viral Gene Expression. Journal of virology. 2015; 89:11144-11149.

28. Pasquier E, Ciccolini J, Carre M, Giacometti S, Fanciullino R, Pouchy C, Montero MP, Serdjebi C, Kavallaris M, Andre N. Propranolol potentiates the antiangiogenic effects and anti-tumor efficacy of chemotherapy agents: implication in breast cancer treatment. Oncotarget. 2011; 2:797-809. doi: 10.18632/oncotarget.343.

29. Perez Pinero C, Bruzzone A, Sarappa MG, Castillo LF, Luthy IA. Involvement of alpha2- and beta2-adrenoceptors on breast cancer cell proliferation and tumour growth regulation. British journal of pharmacology. 2012; 166:721-736.

30. Wilson JM, Lorimer E, Tyburski MD, Williams CL. betaAdrenergic receptors suppress Rap1B prenylation and promote the metastatic phenotype in breast cancer cells. Cancer biology \& therapy. 2015; 16:1364-1374.

31. Banavali S, Pasquier E, Andre N. Targeted therapy with propranolol and metronomic chemotherapy combination: sustained complete response of a relapsing metastatic angiosarcoma. Ecancermedicalscience. 2015; 9:499.

32. Chow W, Amaya CN, Rains S, Chow M, Dickerson EB, Bryan BA. Growth Attenuation of Cutaneous Angiosarcoma With Propranolol-Mediated beta-Blockade. JAMA dermatology. 2015; 151:1226-1229.

33. Pasquier E, André N, Street J, Chougule A, Rekhi B, Ghosh J, Philip DSJ, Meurer M, MacKenzie KL, Kavallaris M, Banavali SD. Effective Management of Advanced Angiosarcoma by the Synergistic Combination of Propranolol and Vinblastine-based Metronomic Chemotherapy: A Bench to Bedside Study. EBioMedicine. 2016; 6:87-95.

34. Hall RA. Beta-adrenergic receptors and their interacting proteins. Seminars in cell \& developmental biology. 2004; 15:281-288.

35. Kassahun WT, Guenl B, Ungemach FR, Jonas S, Abraham G. Expression and functional coupling of liver beta2 - adrenoceptors in the human hepatocellular carcinoma. Pharmacology. 2012; 89:313-320. 
36. Shang ZJ, Liu K, Liang de F. Expression of beta2-adrenergic receptor in oral squamous cell carcinoma. Journal of oral pathology \& medicine. 2009; 38:371-376.

37. Ricci MD, Calvano Filho CM, Oliveira Filho HR, Filassi JR, Pinotti JA, Baracat EC. Analysis of the concordance rates between core needle biopsy and surgical excision in patients with breast cancer. Revista da Associacao Medica Brasileira. 2012; 58:532-536.

38. Bliss CI. The toxicity of poisons applied jointly. Annals of Applied Biology. 1939; 26:1744-7348.

39. Slinker BK. The Statistics of Synergism J Mol Cell Cardiol. 1998; 40:723-731.

40. Gargiulo L, Copsel S, Rivero EM, Gales C, Senard JM, Luthy IA, Davio C, Bruzzone A. Differential beta(2)adrenergic receptor expression defines the phenotype of non-tumorigenic and malignant human breast cell lines. Oncotarget. 2014; 5:10058-10069. doi: 10.18632/ oncotarget. 2460 .

41. Powe DG, Voss MJ, Habashy HO, Zanker KS, Green AR, Ellis IO, Entschladen F. Alpha- and beta-adrenergic receptor (AR) protein expression is associated with poor clinical outcome in breast cancer: an immunohistochemical study. Breast cancer research and treatment. 2011; 130:457-463.

42. Creed SJ, Le CP, Hassan M, Pon CK, Albold S, Chan KT, Berginski ME, Huang Z, Bear JE, Lane JR, Halls ML, Ferrari D, Nowell CJ, et al. beta2-adrenoceptor signaling regulates invadopodia formation to enhance tumor cell invasion. Breast cancer research. 2015; 17:145.

43. Pon CK, Lane JR, Sloan EK, Halls ML. The beta2adrenoceptor activates a positive cAMP-calcium feedforward loop to drive breast cancer cell invasion. FASEB journal. 2016; 30:1144-1154.

44. Cao DX, Wu GH, Yang ZA, Zhang B, Jiang Y, Han YS, He GD, Zhuang QL, Wang YF, Huang ZL, Xi QL. Role of beta1-adrenoceptor in increased lipolysis in cancer cachexia. Cancer science. 2010; 101:1639-1645.

45. McKean-Cowdin R, Li X, Bernstein L, McTiernan A, Ballard-Barbash R, Gauderman WJ, Gilliland F. The ADRB3 Trp64Arg variant and obesity in African-American breast cancer cases. International journal of obesity. 2007; 31:1110-1118.

46. Calvani M, Pelon F, Comito G, Taddei ML, Moretti S, Innocenti S, Nassini R, Gerlini G, Borgognoni L, Bambi F, Giannoni E, Filippi L, Chiarugi P. Norepinephrine promotes tumor microenvironment reactivity through beta3adrenoreceptors during melanoma progression. Oncotarget. 2015; 6:4615-4632. doi: 10.18632/oncotarget.2652.

47. Coelho M, Moz M, Correia G, Teixeira A, Medeiros R, Ribeiro L. Antiproliferative effects of beta-blockers on human colorectal cancer cells. Oncology reports. 2015; 33:2513-2520.

48. Dal Monte M, Casini G, Filippi L, Nicchia GP, Svelto M, Bagnoli P. Functional involvement of beta3-adrenergic receptors in melanoma growth and vascularization. Journal of molecular medicine. 2013; 91:1407-1419.

49. Wolter JK, Wolter NE, Blanch A, Partridge T, Cheng L, Morgenstern DA, Podkowa M, Kaplan DR, Irwin MS. Antitumor activity of the beta-adrenergic receptor antagonist propranolol in neuroblastoma. Oncotarget. 2014; 5:161-172. doi: 10.18632/oncotarget.1083.

50. Borcherding DC, Tong W, Hugo ER, Barnard DF, Fox S, LaSance K, Shaughnessy E, Ben-Jonathan N. Expression and therapeutic targeting of dopamine receptor-1 (D1R) in breast cancer. Oncogene. 2016; 35:3103-3113.

51. Medina VA, Rivera ES. Histamine receptors and cancer pharmacology. British journal of pharmacology. 2010; 161:755-767.

52. Obeid EI, Conzen SD. The role of adrenergic signaling in breast cancer biology. Cancer biomarkers. 2013; 13:161-169.

53. Sarrouilhe D, Clarhaut J, Defamie N, Mesnil M. Serotonin and cancer: what is the link? Current molecular medicine. 2015; 15:62-77.

54. Barretina J, Caponigro G, Stransky N, Venkatesan K, Margolin AA, Kim S, Wilson CJ, Lehar J, Kryukov GV, Sonkin D, Reddy A, Liu M, Murray L, et al. The Cancer Cell Line Encyclopedia enables predictive modelling of anticancer drug sensitivity. Nature. 2012; 483:603-607.

55. Urruticoechea A, Smith IE, Dowsett M. Proliferation marker Ki-67 in early breast cancer. Journal of clinical oncology. 2005; 23:7212-7220.

56. Nasrazadani A, Dwivedi A, Otoukesh S, Arenas J, Padilla O, Alvarado A, Sanchez L, Tfayli A, Nahleh Z. Accuracy of Ki-67 with Recurrence Score and Recurrence Score Pathology - Clinical Assessment in Early Stage Breast Cancer. Annals of Hematology and Oncology. 2014; 1:1011. 